\title{
Purification of ovine transferrin and study of the hormonal control of its secretion in enriched cultures of ovine Sertoli cells
}

\author{
C. Monet-Kuntz, F. Guillou, I. Fontaine and Y. Combarnous \\ Unité 'Biochimie hormonale, Testicule et Spermatozoïde' INRA, Station de Physiologie de la \\ Reproduction, CNRS URA 1291,37380 Nouzilly, France
}

\begin{abstract}
Summary. Ovine transferrin (o-transferrin) was purified from sheep serum by fractionated precipitation with ammonium sulphate, ion-exchange chromatography on DEAE trisacryl and finally by affinity chromatography on Affigel blue to remove albumin. Ovine transferrin was identified by its apparent molecular weight in sodium dodecyl sulphate polyacrylamide gel electrophoresis and by its $N$-terminal amino-acid sequence. The procedure presented in this report permits the preparation of highly purified o-transferrin with a good recovery ( $52 \%$ of initial total immunoactivity).

An antiserum against o-transferrin was then raised in rabbits, using this highly purified preparation. A specific radioimmunoassay was set up using ${ }^{125}$ l-labelled o-transferrin. Its detection threshold $(4 \mathrm{ng} / \mathrm{ml})$ was low enough to measure o-transferrin in spent culture media of ovine Sertoli cells, which ranged between 15 and $600 \mathrm{ng} / \mathrm{ml}$.

Sheep seminiferous tubule cells, containing $\sim 80 \%$ Sertoli cells, were cultured at a high density $\left(1.5 \times 10^{6}\right.$ cells $\left./ \mathrm{cm}^{2}\right)$ on a thin layer of reconstituted basement membrane. Kinetic studies showed that basal daily secretion of o-transferrin was reduced by half $(-49 \%)$ between Day 1 and Day 2 of culture, and progressively decreased thereafter. Under FIRT (500 ng ovine follicle-stimulating hormone (FSH)/ml $+10 \mu \mathrm{g}$ insulin/ $\mathrm{ml}+500 \mathrm{ng}$ retinol $/ \mathrm{ml}+5 \times 10^{-7} \mathrm{~mol} / \mathrm{l}$ testosterone) stimulation, the ratio of stimulated to basal secretions increased 11 -fold between Day 1 (1-1) and Day 6 (12). When $10 \%$ fetal calf serum was added, mean o-transferrin secretion was a third of that in serum-free medium, suggesting that fetal calf serum contains factors that inhibit secretion of ovine Sertoli cell transferrin. In the presence of serum, the ratio of FIRT-stimulated to basal secretions doubled between Day $1(1 \cdot 0)$ and Day $4-6(2 \cdot 0)$.

Between Days 2 and 4 of culture, insulin had a slight stimulatory effect on o-transferrin secretion $(128 \%$ of control at $10 \mu \mathrm{g}$ insulin $/ \mathrm{ml})$, as well as epidermal growth factor $(124 \%$ of control at $50 \mathrm{ng} / \mathrm{ml})$. Testosterone at up to $5 \times 10^{-7} \mathrm{~mol} / 1 \mathrm{had}$ no effect; $500 \mathrm{ng}$ retinol $/ \mathrm{ml}$ doubled o-transferrin secretion $(218 \%$ of control) as did $500 \mathrm{ng} \mathrm{FSH} / \mathrm{ml}$ (220\% of control). A combination of retinol and FSH increased the secretion 4-fold, indicating that maximal stimulation of o-transferrin secretion by ovine Sertoli cells requires the combined actions of mechanisms dependent and independent of cAMP.
\end{abstract}

Keywords: sheep; Sertoli cell; transferrin; retinol; FSH

\section{Introduction}

Sertoli cells are major secretory cells of the testis and constitute the only non-germinal cells of the seminiferous epithelium. They offer structural support to the tubule and are in intimate contact and communication with germinal cells. Tight junctional complexes formed between adjacent Sertoli 
cells comprise a barrier that restricts access to serum components by leptotene spermatocytes and further-developed germinal cells inside the barrier. Sertoli cells are responsible for creating a unique environment in which germinal cells divide and differentiate into spermatozoa. Elucidation of the factors that regulate Sertoli function is required to understand the mechanisms involved in the maintenance and control of spermatogenesis (for review, see Bardin et al., 1988).

In rats, a number of Sertoli cell secretory products have been identified and their functions determined, including the iron-transport protein transferrin (for review, see Griswold et al., 1988). The protein was identified in cell culture media by its ability to bind iron and by its cross-reaction with antibodies to rat sero-transferrin. Further analysis of transferrins derived from Sertoli cells and serum revealed that their peptide backbones were identical, but they exhibited different glycosylation patterns. The proposed function of this protein in testicular cells is to transport iron. It has been postulated that Sertoli cells synthesize and secrete this protein into the seminiferous tubular lumen to provide a mechanism for transport of $\mathrm{Fe}^{3+}$ to developing germ cells. The demonstration of transferrin-specific binding to spermatocytes and of transferrin receptors on spermatids is consistent with this hypothesis.

Studies of seminal fluid in man suggest that $>80 \%$ of seminal transferrin comes from the testes, and show that seminal transferrin is a reliable index of seminiferous tubular function because concentrations of this protein are lower in patients with oligo- and azoospermia (Holmes et al., 1982; Orlando et al., 1985). One study of seminal fluid in bulls indicated that $60 \%$ of seminal transferrin comes from the testes and that there is a relationship between total seminal transferrin and total sperm output (Gilmont et al., 1990). These studies led to the suggestion that the protein might be a good marker of seminiferous tubule function.

In contrast to the abundant information on Sertoli cell function in rat testis, only a few studies have been published concerning domestic species such as sheep. Speight et al. (1984) showed that the proportion of $\left[{ }^{3} \mathrm{H}\right]$ leucine-labelled proteins that were secreted by Sertoli cells of lambs 2-12 weeks old increased with age. Monet-Kuntz et al. (1991) demonstrated the secretion of plasminogen activator, which was enhanced by FSH in Sertoli cells in lambs 3-10 weeks old. In this species, however, nothing was known about the existence of secretion of transferrin by Sertoli cells nor its regulation by hormones.

In this study, we therefore investigated the regulation of transferrin secretion in Sertoli cells from 3-month-old sheep. For this purpose, we needed to set up a radioimmunoassay (RIA) for ovine transferrin (o-transferrin). As neither anti-rat transferrin antibodies (F. Guillou, unpublished data) nor anti-bovine transferrin antibodies (J. M. Guillaumin, personal communication) could recognize o-transferrin, transferrin had to be purified from sheep serum in order to prepare a specific antiserum. The aims of this work were to (i) purify transferrin from ovine serum; (ii) set up a specific RIA for use in spent culture media of ovine Sertoli cells; and (iii) study the regulation of its secretion by factors known to be regulators of its secretion in rats, i.e. follicle-stimulating hormone (FSH), insulin, retinol, epidermal growth factor (EGF and testosterone).

\section{Materials and Methods}

\section{Animals}

Ile-de-France or Préalpes lambs were born throughout the year and were subjected to natural variations in light and temperature. Testes were removed at ages of 83-130 days.

\section{Chemicals}

Iodogen was obtained from Pierce (Rockford, IL, USA). Nonidet P-40, bovine insulin, retinol, sodium selenate, sodium pyruvate, cycloheximide and sodium lactate were purchased from Sigma Chemical Company (St Louis, MO, USA). DEAE trisacryl and Ultroser-G were obtained from IBF (Villeneuve la Garenne, France) and Affigel blue matrix from Amicon (Danvers, MA, USA). Dulbecco`s minimum essential medium was purchased from Gibco 
(Grand Island, NY, USA) and Matrigel from Sochibo (Velizy-Villacoublay, France). Fetal calf serum was purchased from Biomérieux (Charbonnières les Bains. France). Testosterone was obtained from Roussel-Uclaf (Romainville, France) and EGF from Serva (Heidelberg, Germany).

The sheep anti-rabbit $\gamma$-globulin serum was prepared by N. Martinat (INRA, Nouzilly, France), and ovine FSH (CY 1746: $38 \times$ NIH-FSH-SI) was purified in our laboratory.

The 24-well culture plates were obtained from Nunc (Roskilde, Denmark).

\section{Purification of o-transferrin}

Ovine transferrin was first precipitated from sheep serum with $5060 \%$ ammonium sulphate as described by Guerin $e t a l$. (1976) and was a gift from these authors. The precipitate was extensively dialysed against water and lyophylized: $2 \mathrm{~g}$ of protein was applied to a $(7.5 \times 3 \mathrm{~cm})$ column of DEAE trisacryl previously equilibrated with Tris- $\mathrm{HCl}(25 \mathrm{mmol} / \mathrm{l})(\mathrm{pH} 8.8)$ containing $35 \mathrm{mmol} \mathrm{NaCl} / 1$. Bound proteins were recovered by stepwise elution, first with $25 \mathrm{mmol}$ Tris- $\mathrm{HCl} / \mathrm{l}$ (pH 8.6) containing $75 \mathrm{mmol} \mathrm{NaCl} / \mathrm{l}$ and second with $25 \mathrm{mmol}$ Tris- $\mathrm{HCl} / \mathrm{l}$ (pH 7.6) containing $150 \mathrm{mmol} \mathrm{NaCl} / \mathrm{l}$. The first peak containing transferrin was detected by sodium dodecyl sulphate polyacrylamide gel electrophoresis (SDS-PAGE) (Laemmli, 1970) and was desalted on a G25-Sephadex column (Pharmacia, Uppsala, Sweden); $12 \mathrm{mg}$ of this fraction was passed through an Affigel blue $(1 \times 10 \mathrm{~cm})$ column previously equilibrated with $50 \mathrm{mmol}$ Tris $\mathrm{HCl}(\mathrm{pH} 7)$ containing $100 \mathrm{mmol} \mathrm{KCl} / 1$, to remove the albumin contaminant. Albumin was eluted with $50 \mathrm{mmol}$ Tris- $\mathrm{HCl} / 1(\mathrm{pH} 7)$ containing $1.5 \mathrm{~mol} \mathrm{KCl} / 1$.

\section{Determination of $\boldsymbol{N}$-terminal amino-acid sequence}

The purified molecule was reduced with $\beta$-mercaptoethanol and alkylated with 4-vinylpyridine according to Henschen (1986). $N$-terminal sequencing of the reduced and alkylated molecule was performed by automated Edman degradation of the whole protein following the original method of Hewick et al. (1981) on an Applied Biosystems $470 \mathrm{~A}$ sequenator with an on-line PTH-amino acid analyser model $120 \mathrm{~A}$ with the reagents and methods proposed by the manufacturer. This sequence determination was achieved by J. C. Huet and J. C. Pernollet (Protein Study Laboratory, INRA, Versailles, France).

\section{Labelling of o-transferrin and preparation of antiserum}

Anti-ovine transferrin serum was prepared by eight intradermic injections of transferrin ( $100 \mu \mathrm{g} /$ week in Freund's adjuvant) into two rabbits at Days $0,7,14,21,42,49,56$ and 64 . Four weeks after the last injection, $30 \mathrm{ml}$ of blood was collected from each rabbit and the serum was stored at $-20^{\circ} \mathrm{C}$.

Ovine transferrin was labelled with ${ }^{125} \mathrm{I}$ as follows: $2 \mu \mathrm{g}$ of transferrin in $50 \mu \mathrm{l}$ of phosphate buffer $(50 \mathrm{mmol} / \mathrm{l}$, pH 7.4) was put into a tube coated with $25 \mu \mathrm{g}$ iodogen. Then $200 \mu \mathrm{Ci}^{125} \mathrm{I}$ was added and the tube left for $15 \mathrm{~min}$ at $20^{\circ}$ C. The solution was transferred onto a Sephadex G-25 column, which was eluted with 25 mmol veronal buffer $/ 1$ containing $2 \cdot 5(\mathrm{w} / \mathrm{v})$ serum albumin. The mean incorporation of ${ }^{125} \mathrm{I}$ into the protein was $54 \%$; so, the specific activity of iodinated transferrin was $\sim 54 \mu \mathrm{Ci} / \mu \mathrm{g}$.

\section{Radioimmunoassay of o-transferrin}

Standard curves were constructed from 12 doses of o-transferrin ranging between 0.1 and $500 \mathrm{ng}$ in $100 \mu$ culture medium, and assayed in triplicate. When samples of culture medium containing fetal calf serum or fetal calf serum substitute (Ultroser $G$ ) were assayed, fetal calf serum or Ultroser $G$ was added to the o-transferrin standards at the same final concentration. For unknown culture medium samples, duplicate $100 \mu$-aliquants were put into 3-ml polycarbonate tubes. To each tube was added $50 \mu \mathrm{l}$ of iodinated transferrin $(15000$ c.p.m.) in phosphate buffer $(0.1 \mathrm{~mol} / \mathrm{l}$. pH 7.4$)$ containing $0.1 \%$ bovine serum albumin and $0.5 \%$ Nonidet P-40. Then $50 \mu \mathrm{l}$ of rabbit antitransferrin serum (dilution 1:10 000) plus normal rabbit serum $(0.5 \%)$ were added and the tubes were left overnight at room temperature. Separation of bound from free transferrin was achieved by immunoprecipitation: $50 \mu \mathrm{l}$ of sheep anti-rabbit $y$-globulin serum diluted $1: 2$, plus $1 \mathrm{ml}$ polyethylene glycol $_{4000}(6 \%$ in water) were added and the tubes were immediately centrifuged at $2000 \mathrm{~g}$ for $30 \mathrm{~min}$ at $4^{\circ} \mathrm{C}$. The supernatants were discarded and the radioactivity in the pellet was determined using an LKB gamma counter. For calculations, a four-parameter single-binding-site model, which includes antibody concentration, affinity coefficient, non-specific-binding and tracer concentration (Edwards \& Ekins, 1982), was used.

\section{Isolation and culture of an enriched population of ovine Sertoli cells}

The same method as used for the preparation of cells from pig seminiferous tubules was used (Monet-Kuntz \& Fontaine, 1989). Cells were diluted in an appropriate volume of culture medium to yield $\sim 6 \times 10^{6}$ seminiferous tubule cells/ml. The culture medium was nearly identical to that described by Hadley et al. (1985) and consisted of 
Dulbecco's minimum essential medium (DMEM) supplemented with glutamine ( $2 \mathrm{mmol} / \mathrm{l})$, insulin $(2 \mu \mathrm{g} / \mathrm{ml})$, human transferrin $(5 \mu \mathrm{g} / \mathrm{ml})$, vitamin A $(50 \mathrm{ng}$ retinol $/ \mathrm{ml})$, vitamin $\mathrm{E}(200 \mathrm{ng} / \mathrm{ml})$, sodium selenate $(5 \mathrm{ng} / \mathrm{ml})$, sodium pyruvate $(1 \mathrm{mmol} / \mathrm{l})$ and sodium lactate $(22 \mathrm{mmol} / \mathrm{l})$. Fungizone $(2.5 \mu \mathrm{g} / \mathrm{ml})$, penicillin $(100 \mathrm{units} / \mathrm{ml})$ and streptomycin $(100 \mu \mathrm{g} /$ $\mathrm{ml}$ ) were added. In some culture experiments, $10 \%$ fetal calf serum or a calf serum substitute ('Ultroser $\mathrm{G}$ ') was added at a final concentration of $0.02,0.2$ or $2 \%$, as data from the manufacturer indicated that the cell-growth-promoting activity of $2 \%$ Ultroser $G$ was the same as that of $10 \%$ fetal calf serum.

Reconstituted basement membrane (RBM) extracellular matrix prepared by high salt and urea extraction of the EHS mouse tumour (Kleinman et al., 1986) is marketed under the name Matrigel; $\sim 250 \mu$ of RBM matrix diluted 1:1 v/v with DMEM was applied to the bottom of the wells, the excess of matrix was immediately aspirated and polymerization was achieved by incubation at $34^{\circ} \mathrm{C}$ for $30 \mathrm{~min}$.

Samples of $500 \mu \mathrm{l}$ of cell suspension were distributed into 24 -well plates which had been coated with a thin layer of RBM matrix, yielding a density of $1.5 \times 10^{6}$ seminiferous tubule cells $/ \mathrm{cm}^{2}$.

Cells in coated culture plates were incubated at $34 \mathrm{C}$ in a humidified atmosphere of $95 \%$ air: $5 \%$ CO, (Day 0 of culture). Hormones and factors were added on either Day 0 or Day 2, depending on the experiment (see Results).

\section{Identification of the different types of seminiferous tubule cells}

Peritubular cells in the seminiferous tubule cell suspension were identified by examination of alkaline phosphatase activity. Cells were fixed and stained as described by Chapin et al. (1987), except that the reaction mixture was incubated for $5 \mathrm{~min}$ instead of $10 \mathrm{~min}$.

Germ cells were identified according to morphological criteria using light microscopy (Ortavant, 1959). The cell suspension was fixed with $2 \%$ glutaraldehyde and $0 \cdot 5 \%$ potassium hexacyanoferrate (III) in sodium cacodylate buffer $(0.175 \mathrm{~mol} / \mathrm{pH} 7 \cdot 25)$. Cells were fixed in $2 \%$ osmium tetroxide, dehydrated in ethanol and embedded in Epon. Semithin $(1 \mu \mathrm{m})$ sections were stained with toluidine blue dye.

A typical preparation of seminiferous tubule cells contained $3 \%$ peritubular cells and $5 \%$ germ cells, which indicated that it contained $\sim 80 \%$ Sertoli cells.

\section{Statistical analyses}

To analyse the effects of different factors on transferrin secretion in different culture experiments, a two-way analysis of variance was performed.

\section{Results}

\section{Purification of o-transferrin}

During purification, o-transferrin was identified by its apparent molecular weight in SDSPAGE. Transferrin was eluted in the first peak of ion-exchange chromatography on DEAE trisacryl (Fig. 1). As transferrin was still contaminated with albumin at this stage, we performed an affinity chromatography on Affigel blue matrix. Two peaks were separated (Fig. 2). and SDSPAGE showed that only a single band with an apparent $\mathbf{M}_{r}$ of 75000 (corresponding to transferrin) was present in the first peak. Albumin was present only in the second peak.

The $N$-terminal amino-sequencing of the purified molecule up to the 11 th residue (Table 1) strongly suggested that it was o-transferrin.

The purification procedure yielded $64 \mathrm{mg}$ of o-transferrin from $2 \mathrm{~g}$ of ammonium sulphate precipitate produced from $64 \mathrm{ml}$ of sheep serum (Table 2). A recovery of $52 \%$ of the starting total immunoactivity was obtained.

\section{Characteristics of the o-transferrin assay in culture media}

Specificity of the antisera. Since human transferrin (h-transferrin) is a component of the culture medium, it is important to distinguish secreted o-transferrin from added h-transferrin. With the antiserum 188, h-transferrin exhibits a cross-reactivity of $<0.2 \%$ (Fig. 3). This allows specific assay of o-transferrin in culture tubes to which $5 \mu \mathrm{g} / \mathrm{ml}(500 \mathrm{ng} /$ assay tube $)$ h-transferrin was added. Rat transferrin had a cross-reactivity of $<0.5 \%$. The second peak from Affigel blue elution was used as a source of o-albumin and exhibited a cross-reactivity of $1.4 \%$. With antiserum 189 from the other 


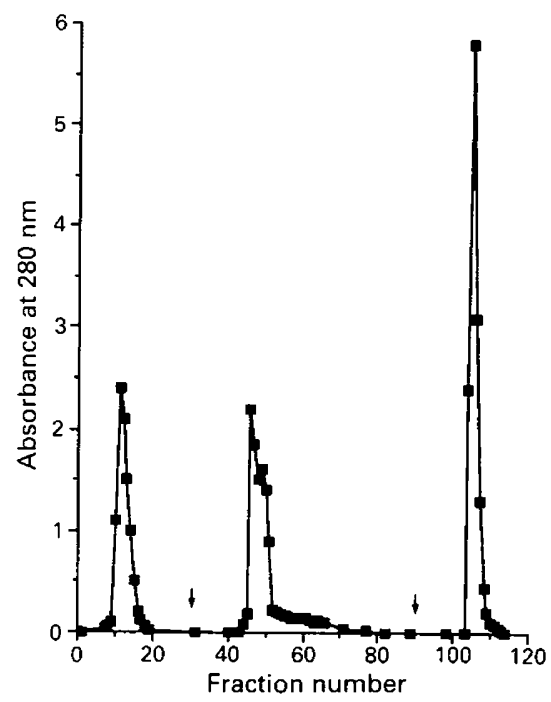

Fig. 1. DEAE trisacryl chromatography of proteins precipitated from sheep serum by ammonium sulphate. A sample of $1.2 \mathrm{ml}(2 \mathrm{~g})$ was applied to a $7.5 \times 3 \mathrm{~cm}$ column equilibrated with Tris- $\mathrm{HCl}(25 \mathrm{mmol} / 1, \mathrm{pH} 8.8)$ containing $35 \mathrm{mmol} \mathrm{NaCl} / \mathrm{l}$. The arrows show buffer changes at fraction No. $30(25 \mathrm{mmol}$ Tris $-\mathrm{HCl} / 1, \mathrm{pH} 8.6$, containing $75 \mathrm{mmol} \mathrm{NaCl} / \mathrm{l})$ and at fraction No. $90(25 \mathrm{mmol}$ Tris- $\mathrm{HCl} / 1, \mathrm{pH} 7 \cdot 6$, containing $150 \mathrm{mmol} \mathrm{NaCl} / \mathrm{l})$. The flow was $1 \mathrm{ml} / \mathrm{min}$, and $3-\mathrm{ml}$ fractions were collected and monitored at $280 \mathrm{~nm}$.

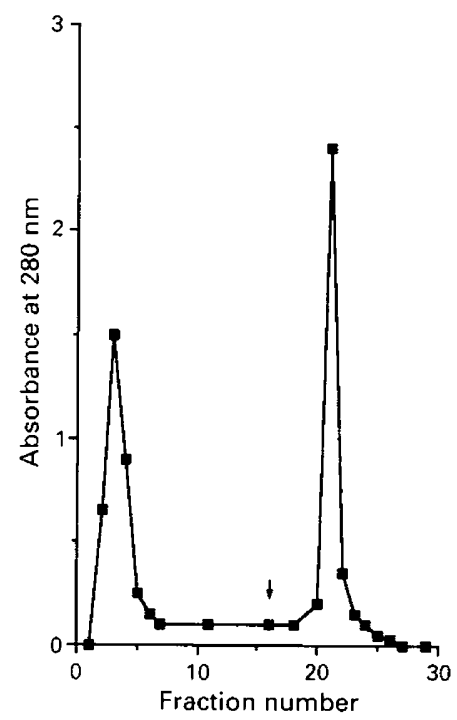

Fig. 2. Affinity chromatography on Affigel blue of fraction I from DEAE trisacryl containing ovine transferrin. A 2-ml sample $(12 \mathrm{mg})$ was applied onto a $1 \mathrm{~cm} \times 10 \mathrm{~cm}$ column equilibrated with Tris $-\mathrm{HCl}(50 \mathrm{mmol} / \mathrm{l}, \mathrm{pH}$ 7) containing $100 \mathrm{mmol} \mathrm{KCl} / \mathrm{l}$. The arrow shows a buffer change at fraction No. $16(50 \mathrm{mmol}$ Tris $-\mathrm{HCl} / 1, \mathrm{pH} 7$, containing $1.5 \mathrm{~mol} \mathrm{KCl} / 1)$. The flow was $0.5 \mathrm{ml} /$ $\mathrm{min}$, and $1-\mathrm{ml}$ fractions were monitored at $280 \mathrm{~nm}$. 
Table 1. Comparison of the $N$-terminal sequence of the ovine transferrin preparation described in this work with previously published sequences of transferrins (or ovotransferrins) from different species

\begin{tabular}{|c|c|c|}
\hline & & 10 \\
\hline This work & Reference & Asp-Pro-Glu- Lys-Thr-Val- Ile- Trp-Cys-Thr-Ile- ... \\
\hline Sheep & Guerin et al., 1976 & Ser-Pro-Glu-Lys-Thr-Val-Ile- Trp- \\
\hline Cow & Brock et al. 1980 & Asp-Pro-Glu-Arg-Thr-Val- . . \\
\hline Pig & Graham \& Williams, 1975 & Val- Pro-Glu-Lys-Thr- \\
\hline Rat & Aldred et al., 1984 & Val- Pro-Asp-Lys-Thr-Val- ? -Trp-Cys-Ala-Val- \\
\hline Man & MacGillivray et al., 1983 & Val- Pro-Asp-Lys-Thr-Val-Arg-Trp-Cys-Ala-Val- \\
\hline Chicken & Graham \& Williams, 1975 & Ala- Pro-Pro- Lys-Ser- Val- Arg-Trp-Cys-Thr-Ile- . \\
\hline
\end{tabular}

Table 2. Yield and recovery of ovine transferrin

\begin{tabular}{lrccc}
\hline & \multicolumn{3}{c}{ Activity* } \\
& $\begin{array}{c}\text { Yield } \\
(\mathrm{mg})\end{array}$ & $\begin{array}{c}\text { Specific } \\
(\mathrm{mg} / \mathrm{mg})\end{array}$ & $\begin{array}{c}\text { Total } \\
(\mathrm{mg})\end{array}$ & $\begin{array}{c}\text { Recovery } \\
(\%)\end{array}$ \\
\hline Ammonium sulphate precipitate & 2000 & $0 \cdot 06$ & 122 & 100 \\
DEAE trisacryl elution-peak I & 386 & 0.26 & 100 & 82 \\
Affigel blue matrix elution-peak I & 64 & $1 \dagger$ & 64 & 52 \\
\hline
\end{tabular}

*As determined by radioimmunoassay.

† Served as the standard for o-transferrin radioimmunoassay.

rabbit, cross-reactions were the same (data not shown), but all the o-transferrin assays reported in this study were performed using the antiserum 188.

Sensitivity of the assay. The standard curve sensitivity was $0.4 \mathrm{ng}$ of o-transferrin, determined as the first dose of the standard curve which yielded a bound (B) value statistically different from unbound $\left(B_{0}\right)$. As $100-\mu$ l aliquots of culture medium samples were assayed, the sensitivity of the assay was $4 \mathrm{ng} / \mathrm{ml}$ cultured medium.

Specificity of the assay. A parallelism test was applied to a pool of culture media, obtained from enriched cultures of ovine Sertoli cells, which was assayed against o-transferrin standards diluted in culture medium (Fig. 4). The slope of the line obtained with the culture medium pool was not different from the slope of the standard curve $(P>0.05)$.

Precision of the assay. The intra- and interassay precisions were $15(n=20)$ and $22 \%(n=9)$, respectively, for a culture medium pool yielding a $\mathrm{B}: \mathrm{B}_{0}$ ratio of $30 \%$.

\section{Influence of the day of culture on o-transferrin secretion: effect of serum supplementation}

The influence of the day of culture on transferrin secretion by sheep Sertoli cells was investigated over 6 days (Fig. 5a). Cells were plated on Day 0 , and an inhibitor of protein synthesis, cycloheximide $(10 \mu \mathrm{g} / \mathrm{ml})$ or FIRT $\left(500 \mathrm{ng}\right.$ o-FSH $/ \mathrm{ml}+10 \mu \mathrm{g}$ insulin $/ \mathrm{ml}+500 \mathrm{ng} \mathrm{retinol} / \mathrm{ml}+5 \times 10^{-7} \mathrm{~mol}$ testosterone/l) was immediately added. The medium was changed and factors added every $24 \mathrm{~h}$ for 6 days. Basal daily transferrin secretion was halved $(-49 \%)$ between Days 1 and 2 of culture, and decreased slightly thereafter. On Day 1, preformed transferrin represented the greater part $(65 \%)$ of basal secretion, whereas it represented $<20 \%$ on Days 2 to 4 . Under FIRT stimulation, transferrin secretion increased sharply, the ratio of stimulated secretion to basal secretion increasing 11-fold between Day 1 (1-1) and Day 6 (12).

To prevent the marked decrease in basal transferrin secretion during the 6 days of culture, $10 \%$ fetal calf serum was added to the culture medium (Fig. 5b). Transferrin secretion in the presence of 


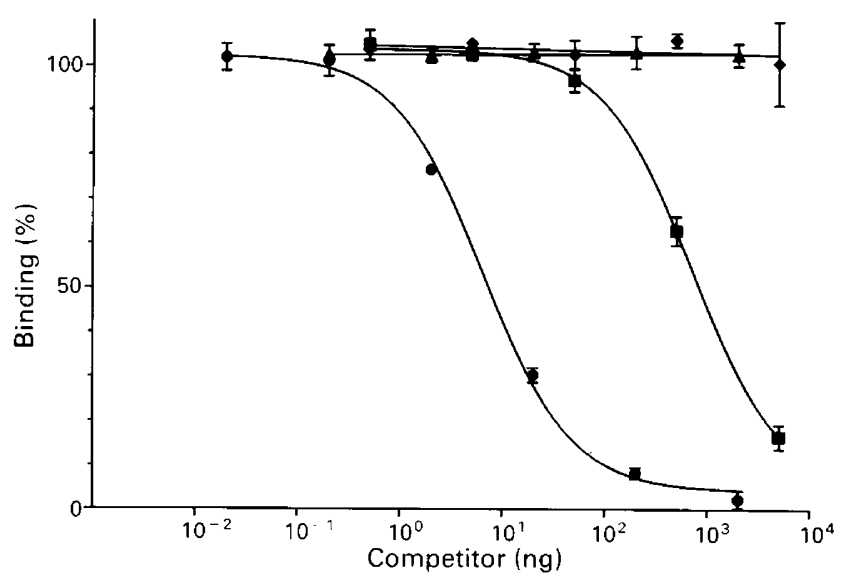

Fig. 3. Competition curves for the binding of purified ovine transferrin ( ), human transferrin $(\bullet)$, rat transferrin $(\Delta)$ and ovine albumin $(\boldsymbol{Q})$ with ${ }^{125}$ I-labelled ovine transferrin to rabbit anti-ovine transferrin antibody. Data are means \pm s.d. $(n=3)$.

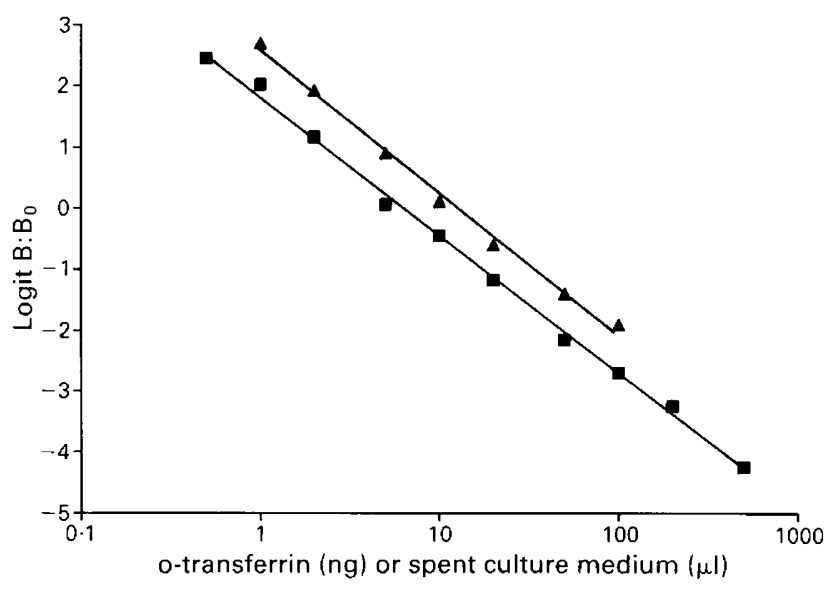

Fig. 4. Relationship between volume of a pool of culture medium $(\Delta)$ and amount of ovine (o) transferrin diluted in culture medium $(\boldsymbol{\square})$. Data are means $(n=3)$. Logit (bound $(\mathbf{B})$ : unbound $\left(\mathrm{B}_{0}\right)=\log \left(\mathrm{B}: \mathrm{B}_{0}\right) / 1-\left(\mathrm{B}: \mathrm{B}_{0}\right)$.

serum was about a third of that in the absence of serum, from the first day of culture. Basal transferrin secretion was halved $(-45 \%)$ between Day 1 and Day 2 of culture, and increased 5-fold between Days 2 and 6. On Day 1, preformed transferrin represented the greater part (77\%) of the basal secretion, whereas it became undetectable afterwards. Under FIRT stimulation, transferrin secretion increased 5-fold from Day 1 to Day 6. However, the ratio of stimulated to basal secretion doubled between Day $1(1 \cdot 0)$ and Days 4-6 (2.0). Therefore, at the end of the culture period, this ratio was about six times lower in the presence of serum than in its absence.

Similar experiments were performed using the fetal calf serum substitute Ultroser $\mathrm{G}$ for 4 days in culture. With $2 \%$ Ultroser $G$, results were identical to those obtained with $10 \%$ fetal calf serum; 

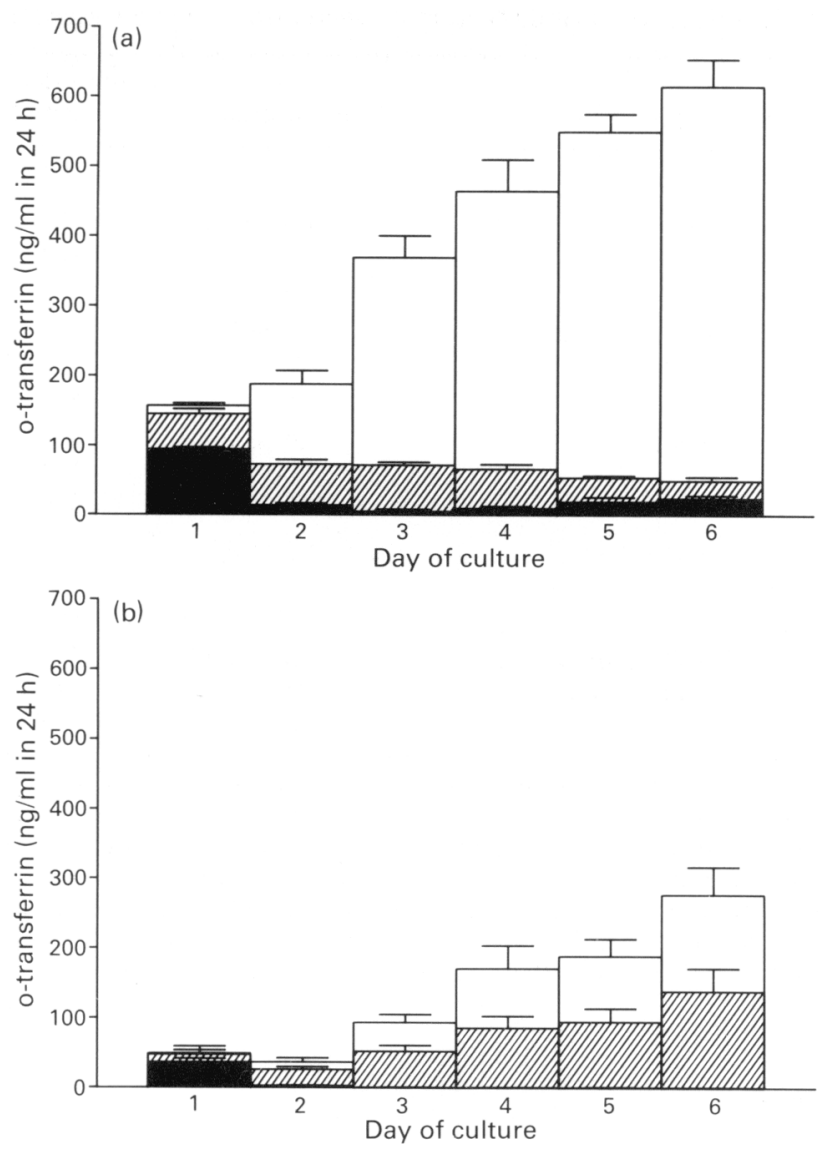

Fig. 5. Daily secretion of ovine (o) transferrin by enriched cultures of sheep Sertoli cells. Cells were cultured in the absence (a) or presence (b) of $10 \%$ fetal calf serum; ( $) 10 \mu \mathrm{g}$ cycloheximide/ml, $(\square)$ control, $(\square)$ FIRT $500 \mathrm{ng}$ follicle-stimulating hormone $/ \mathrm{ml}+10 \mu \mathrm{g}$ insulin/ $\mathrm{ml}+500 \mathrm{ng} \mathrm{retinol} / \mathrm{ml}+5 \times 10^{-7} \mathrm{~mol}$ testosterone $\left./ \mathrm{l}\right)$. Data are means \pm s.d. $(n=4$ culture wells).

$0.02 \%$ and $0 \cdot 2 \%$ Ultroser gave intermediate results between 0 and $2 \%$ Ultroser, showing a dose-dependent inhibition of o-transferrin secretion (data not shown).

Since the aim of the study was to test the stimulating effect of different factors upon transferrin secretion, the following culture experiments were performed in serum-free medium. Cells were cultured for 2 days without any factor, and then 2 days in the presence of various factors.

\section{Regulation of o-transferrin secretion}

To investigate the effect of various factors, cells were cultured in medium lacking in insulin and retinol, and the factors were individually added on Day 2, at three concentrations. Secretion of transferrin was slightly stimulated by the higher concentrations of insulin and EGF and doubled by retinol and FSH (Table 3), but was not affected by testosterone.

To determine whether the two more efficient stimulating factors, retinol and $\mathrm{FSH}$, have additive or synergistic effects on transferrin secretion, two culture experiments were conducted. Retinol $(500 \mathrm{ng} / \mathrm{ml})$ or FSH $(500 \mathrm{ng} / \mathrm{ml})$ increased transferrin secretion 2-fold, and a combination of the two factors at these concentrations increased the secretion 4-fold (Fig. 6). 
Table 3. Effects of various factors on secretion of ovine transferrin

\begin{tabular}{clcc}
\hline $\begin{array}{c}\text { Number of } \\
\text { experiments }\end{array}$ & Supplement & Concentration & $\begin{array}{c}\text { o-transferrin } \\
(\% \text { control })\end{array}$ \\
\hline \multirow{3}{*}{4} & None & $0 \cdot 4 \mu \mathrm{g} / \mathrm{ml}$ & $100^{\mathrm{a}}$ \\
& Insulin & 2 & $117^{\mathrm{b}}$ \\
4 & & 10 & $119^{\mathrm{b}}$ \\
& Epidermal growth & $2 \mathrm{ng} / \mathrm{ml}$ & $128^{\mathrm{c}}$ \\
& factor & 10 & $108^{\mathrm{ab}}$ \\
3 & & 50 & $110^{\mathrm{ab}}$ \\
& Retinol & $20 \mathrm{ng} / \mathrm{ml}$ & $124^{\mathrm{b}}$ \\
& & 100 & $138^{\mathrm{b}}$ \\
4 & Testosterone & 500 & $218^{\mathrm{b}}$ \\
& & $10 \cdot 2 \times 10^{-7} \mathrm{~mol} / 1$ & $101^{\mathrm{a}}$ \\
& & 1 & $97 \cdot 5^{\mathrm{a}}$ \\
5 & Follicle-stimulating & 5 & $104^{\mathrm{a}}$ \\
& hormone & $20 \mathrm{ng} / \mathrm{ml}$ & $102^{\mathrm{a}}$ \\
& & 100 & $144^{\mathrm{b}}$ \\
& & 500 & $220^{\mathrm{c}}$ \\
\hline
\end{tabular}

Each factor was tested in three to five culture experiments. Cells were cultured for 2 days in culture medium lacking insulin and retinol; on Day 2, the medium was changed and factors were added at the indicated concentration to four culture wells. Spent medium was collected on Day 4 . In each experiment, the concentration of transferrin secreted in the presence of cycloheximide $(10 \mu \mathrm{g} / \mathrm{ml})$ has been subtracted. For each factor, numbers with different letter superscripts are significantly different $(P<0.05)$ when tested by analysis of variance.

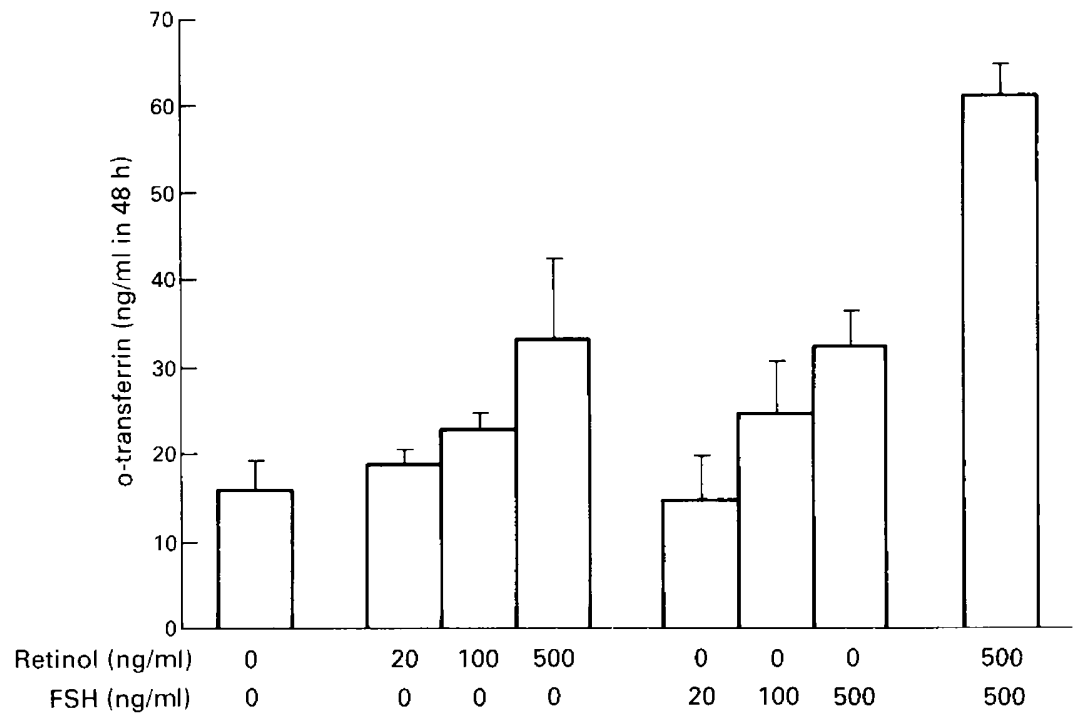

Fig. 6. Effects of retinol and follicle-stimulating hormone (FSH) on secretion of ovine (o) transferrin. Cells from two experiments were cultured for 2 days in medium lacking insulin and retinol. On Day 2, the medium was changed and retinol or FSH was added to four replicate culture wells. Spent medium was collected on Day 4. In each experiment, the concentration of pre-formed transferrin secretion has been subtracted from all the values of transferrin secretion. Data are means \pm s.d. ( $n=8$ culture wells). 


\section{Discussion}

This paper describes an efficient purification scheme permitting the preparation of large quantities of o-transferrin. During its purification, the presence of the protein in the different fractions was detected only by its behaviour in SDS-PAGE. Indeed, there is generally no cross-reaction in the immunoassays of transferrins from different species and, accordingly, we found that the ovine molecule was not detectable in the assays for bovine and rat transferrins. The identification of o-transferrin was finally confirmed by $N$-terminal sequencing of its polypeptide chain. Eleven residues were determined, while only eight $N$-terminal amino-acid residues had been previously determined (Guerin et al., 1976). The comparison with the sequence found in the present work shows complete identity except for the $N$-terminal residue (Asp instead of Ser). Bovine transferrin possesses an $N$-terminal sequence similar to the one we found here for the ovine molecule (including the terminal Asp), but with Arg instead of Lys in the fourth position in all the other sequences. Taken together, the comparison of the sequences (Table 1) strongly indicates that the molecule we purified is o-transferrin.

This o-transferrin preparation was used to set up an RIA which appeared specific. The parallelism test did not reveal any interference of compounds secreted by the cells into the culture medium. The fact that o-albumin exhibited some cross-reactivity in the assay might be explained in two ways: (a) peak II from Affigel blue elution (o-albumin) might still contain 1-2\% transferrin; or (b) peak I from Affigel blue chromatography might be slightly contaminated with albumin, which would have led to the production of some anti-o-albumin antibodies in addition to anti-o-transferrin antibodies. The two hypotheses, which are not mutually exclusive, cannot be tested as neither pure o-albumin nor anti-o-albumin are available.

The RIA developed in our laboratory is sensitive enough to detect o-transferrin in spent culture medium of Sertoli cells. Only occasionally were the concentrations of o-transferrin in spent media from cells cultured in the presence of cycloheximide under the limit of detection of the assay ( $4 \mathrm{ng} / \mathrm{ml})$.

In the absence of serum, basal secretion of o-transferrin decreased 2-fold between Days 1 and 2 of culture and decreased little thereafter, though our culture medium contained insulin $(2 \mu \mathrm{g} / \mathrm{ml})$ and retinol $(50 \mathrm{ng} / \mathrm{ml})$. In 20-day-old rats, Skinner \& Griswold (1982) reported a dramatic fall in $\mathrm{r}$-transferrin secretion during 8 days in culture in F12 medium, which occurred even after the addition of retinol $(100 \mathrm{ng} / \mathrm{ml})$, but was prevented by the addition of retinol plus insulin $(5 \mu \mathrm{g} / \mathrm{ml})$. In the same species, Perez-Infante et al. (1986) observed that $r$-transferrin secretion by cells derived from young animals ( $\leqslant 19$ days old) markedly decreased during 10 days in culture in basal culture medium. The addition of retinoic acid $(50 \mathrm{ng} / \mathrm{ml})$ maintained $\mathrm{r}$-transferrin secretion throughout the culture period. The discrepancy between these two groups could be due either to the form of vitamin A used, or to the composition of the basal medium. Janecki \& Steinberger (1987) also observed that in basal medium r-transferrin secretion gradually decreased from Days 1-3 to Days 11-13. In the present study, after FIRT addition, the ratio of stimulated o-transferrin upon basal secretion increased sharply between Days 1 and 6 of culture. In rat Sertoli cells cultured on plastic or on a Millipore filter, the magnitude of $r$-transferrin secretion stimulation by FIRT was maximal between Days 4 and 6 (Skinner \& Griswold, 1982; Janecki \& Steinberger, 1987; Skinner et al., 1989a). When cells were plated onto RBM matrix, stimulated r-transferrin production rose from Day 2 to Day 4 and decreased gradually from Day 4 to Day 8 of culture (Tananis Anthony et al., 1989). In human Sertoli cell cultures, Holmes et al. (1984) observed maximal FIT-stimulated secretion (i.e. no retinol) of h-transferrin on Day 5 of culture. Thus it appears that in cultures of sheep Sertoli cells as well as in other species, transferrin secretion can be more efficiently stimulated by the combination of $\mathrm{FSH}$, insulin, retinol and testosterone and that the ratio of stimulated to basal secretions increases up to Day 6 of culture.

In the presence of fetal calf serum, the average concentration of secreted o-transferrin was about a third of that in serum-free medium. This result is different from those reported in rats, 
where fetal bovine serum is the most effective stimulant of $r$-transferrin secretion (Perez-Infante et al., 1986; Janecki \& Steinberger, 1987). Thus it seems that fetal calf serum contains one or more factors that inhibit transferrin secretion in sheep Sertoli cells. The partial purification of fetal calf serum to yield the substitute Ultroser $G$ does not eliminate this effect. The complex nature of serum makes it impossible to ascertain which factor is responsible for the inhibition of o-transferrin secretion. It would probably be easier to look for this factor in Ultroser-G if the manufacturer disclosed its composition. However, we do not know whether the negative effect of serum is specific for o-transferrin secretion or whether it extends to other secretions or functions. After FIRT addition, the ratio of FIRT-stimulated to basal secretions was lower than in serum-free cultures. Similarly, in cultures of rat Sertoli cells, Mather et al. (1984) reported that serum supplementation markedly reduced the adenylate cyclase response to FSH. Likewise, Monaco et al. (1989) reported that both FSH-dependent stimulation of c-AMP accumulation and androgen aromatization were inhibited in a dose-dependent fashion by fetal bovine serum. They hypothesized that serum contains heat-stable, non-dialysable factors that affect the response of Sertoli cells to FSH, possibly by activation of polyphosphoinositide turnover, or by stimulating cAMP degradation by activating a calcium-calmodulin-dependent phosphodiesterase. However, neither the identity of the serum factor(s) nor its mechanism of action have been determined.

O-transferrin secretion by sheep Sertoli cells was slightly increased by insulin and EGF and was doubled by retinol and FSH. Testosterone had no effect. In rats, factors that regulate transferrin secretion have been studied extensively (Skinner \& Griswold, 1982; Perez-Infante et al., 1986) as well as factors regulating transferrin mRNA synthesis in vitro and in vivo (Huggenvik et al., 1987; Hugly \& Griswold, 1987; Skinner et al., 1989a). FSH, insulin, retinol and, to a lesser extent, EGF have been shown to induce significant increases in $r$-transferrin secretion. The case of testosterone is somewhat controversial, since some authors reported a small stimulatory effect (Perez-Infante et al., 1986; Huggenvik et al., 1987), whereas others found no significant effect (Skinner et al., 1989a). In cows, transferrin secretion by cultures of immature Sertoli cells is stimulated by FSH, retinol, insulin, EGF and, to a lesser extent, testosterone (Jenkins \& Ellison, 1989). In man, only FSH and insulin have been tested in Sertoli cell cultures and they both exhibited stimulatory effects (Holmes et al., 1984). So, it appears that the hormonal control of testicular transferrin secretion is similar in these mammalian species.

The action of insulin on Sertoli cells requires high concentrations, and has been shown to act through the insulin-like growth factor I receptors. Insulin-like growth factor I is probably the primary mediator of most of the effects of insulin on Sertoli cells, such as the increased production of lactate and synthesis of cell proteins (for a review, see Bellve \& Zheng, 1989). The mechanism of action of EGF on Sertoli cell function is unclear. Receptors for EGF and growth factor- $\alpha$ exist in rat peritubular cells, but not in Sertoli cells or germ cells; it is therefore, hypothesized that the effects of EGF on Sertoli cell functions might be indirect via contaminating peritubular cells (Skinner et al., 1989b).

In sheep, two of the principal factors regulating transferrin secretion are FSH and retinol, and their effects are additive. FSH action is mediated via the adenylate cyclase-protein kinase A system. Retinoids exert their actions through binding to an intracellular DNA-binding protein belonging to the thyroid/steroid hormone receptor family. This indicates that maximal stimulation of transferrin secretion requires the combined actions of mechanisms dependent and independent of cAMP.

We thank G. Guérin for giving us the 50-60\% ammonium sulphate precipitate from sheep serum; J. M. Guillaumin for testing o-transferrin in his bovine transferrin RIA; and J. C. Huet and J. C. Pernollet for determination of $N$-terminal amino-acid sequence of o-transferrin. 


\section{References}

Aldred, A.R., Howlett, G.J. \& Schreiber, G. (1984) Synthesis of rat transferrin in Escherichia coli containing a recombinant bacteriophage. Biochem. Biophys. Res. Com. 122, 960-965.

Bardin, W., Cheng, Y., Musto, N. \& Gunsalus, G. (1988) The Sertoli cell. In The Physiology of Reproduction, pp. 933-974. Eds E. Knobil \& J. Neill. Raven Press, NY.

Bellve, A. \& Zheng, W. (1989) Growth factors as autocrine and paracrine modulators of male gonadal functions. J. Reprod. Fert. 85, 771793.

Brock, J., Esparza, I., Oliver, R. \& Spooner, R. (1980) Electrophoretic mobility of $\mathrm{N}$ - and C-terminal monoferric fragments of bovine transferrin phenotypes AA, D1D1, D2D2, and EE, and N-terminal amino acid sequences. Biochem. Genet. 18, 85I-860.

Chapin, R., Phelps, J., Miller, B. \& Gray, T. (1987) Alkaline phosphatase histochemistry discriminates peritubular cells in primary rat testicular cell culture. J. Androl. 8, 155-161.

Edwards, P.R. \& Ekins, R.P. (1982) Development of a micro-computer radioimmunoassay data processing program for distribution by the World Health Organization. In Radioimmunoassay and Related Procedures in Medicine 1982, pp. 423-442. IAEA, Vienna.

Gilmont, R., Senger, P., Sylvester, S. \& Griswold, M. (1990) Seminal transferrin and spermatogenic capability in the bull. Biol. Reprod. 43, 151-157.

Graham, I. \& Williams, J. (1975) Comparison of glycopeptides from the transferrins of several species. Biochem. J. 145, 263-279.

Griswold, M., Morales, C. \& Sylvester, S. (1988) Molecular biology of the Sertoli cell. In Oxford Reviews of Reproductive Biology, pp. 124-161. Ed. J. R. Clarke. Oxford University Press, Oxford.

Guerin, G., Vreeman, H. \& Nguyen, T. (1976) Préparation et caractérisation physico-chimique partielle de la transferrine sérique ovine. Eur. J. Biochem. 67, 433-445.

Hadley, M., Byers, S., Suarez-Quian, C., Kleinman, H. \& Dym, M. (1985) Extracellular matrix regulates Sertoli cell differentiation, testicular cord formation, and germ cell development in vitro. J. Cell. Biol. 101, 1511-1522.

Henschen, A. (1986) Analysis of cyst(e)in residues, disulfide bridges, and sulfhydryl groups in proteins. In Advanced Methods in Protein Microsequence Analysis, pp. 244-256. Eds B. Wittman-Liebold, J. Sainikowl \& Y. A. Erdmann. Springer Verlag, Berlin.

Hewick, R.M., Hunkapiller, M.W., Hood, L.E. \& Dreyer, W.J. (1981) A gas-liquid solid phase peptide and protein sequenator. J. Biol. Chem. 256, 7990-7997.

Holmes, S., Lipshultz, L. \& Smith, R. (1982) Transferrin and gonadal dysfunction in man. Fert. Steril. 38, 600-604.

Holmes, S., Lipshultz, L. \& Smith, R. ( 1984) Regulation of transferrin secretion by human Sertoli cells cultured in the presence or absence of human peritubular cells. J. Clin. Endocr. Metab. 53, 1058-1062.

Huggenvik, J., Idzerda, R., Haywood, L., Lee, D., McKnight, G. \& Griswold, M. (1987) Transferrin messenger ribonucleic acid: molecular cloning and hormonal regulation in rat Sertoli cells. Endocrinology 120, 332-340.
Hugly, S. \& Griswold, M. (1987) Regulation of levels of specific Sertoli cell mRNAs by vitamin A. Devl Biol. 121, 316-324.

Janecki, A. \& Steinberger, A. (1987) Bipolar secretion of androgen-binding protein and transferrin by Sertoli cells cultured in a two-compartment culture chamber. Endocrinology 120, 291-298.

Jenkins, N. \& Ellison, J. (1989) Regulation of transferrin secretion in Sertoli cells of the calf testis. Anim. Reprod. Sci. 20, 11-20.

Kleinman, H., McGarvey, M., Hassell, J., Star, V., Cannon, F., Laurie, G. \& Martin, G. (1986) Basement membrane complexes with biological activity. Biochemistry 25, 312-318.

Laemmli, U.K. (1970) Cleavage of structural proteins during the assembly of the head of bacteriophage T4. Nature, Lond. 227, 680-683.

Mather, J., Bardin, W., Byer, A. \& Salomon, Y. (1984) Modulation of adenylate cyclase activity in Sertoli cells in vitro. In Recent Progress in Cellular Endocrinology of the Testis (Coll. INSERM, vol. 123), pp. 183-186. Eds J. M. Saez, M. G. Forest, A. Dazord \& J. Bertrand. John Libbey, Paris.

MacGillivray, R.T.A., Mendez, E., Shewale, J.G., Sinha, S.K., Lineback-Zins, J. \& Brew, K. (1983) The primary structure of human serum transferrine. $J$. Biol. Chem. 258, 3543-3553.

Monaco, L., Adamo, S., Stefanini, M. \& Conti, M. (1989) Signal transduction in the Sertoli cell: serum modulation of the response to FSH. J. Steroid. Biochem. 32, $129 \cdots 134$.

Monet-Kuntz, C. \& Fontaine, I. (1989) Age-dependent changes in the in-vitro response of a pig Sertoli cellenriched population to FSH. J. Reprod. Fert. 86, 643-651.

Monet-Kuntz, C., Guillou, F., Fontaine, I. \& Combarnous, Y. (1991) Equine follicle-stimulating hormone action in cultured Sertoli cells from rat, sheep and pig. Acta endocr., Copnh. 125, 86-92.

Orlando, C., Caladini, A., Barni, T., Wood, W. \& Strasburger, C. (1985) Ceruloplasmin and transferrin in human seminal plasma: are they an index of seminiferous tubular function. Fert. Steril. 43, $280-284$.

Ortavant, R. (1959) Le cycle spermatogénétique chez le bélier. Ann. Zootech. 8, 184-244 and 271-322.

Perez-Infante, V., Bardin, W., Gunsalus, G., Musto, N., Rich, K. \& Mather, J. (1986) Differential regulation of testicular transferrin and ABP secretion in primary cultures of rat Sertoli cells. Endocrinology 118, 383392.

Skinner, M. \& Griswold, M. (1982) Secretion of testicular transferrin by cultured Sertoli cells is regulated by hormones and retinoids. Biol. Reprod. 27, $211-221$.

Skinner, M., Takack, K. \& Coffey, R. (1989a) TGF- $\alpha$ gene expression and action in the seminiferous tubule: peritubular cell-Sertoli cell interactions. Endocrinology 124, 845-854.

Skinner, M., Schlitz, S. \& Tananis Anthony, C. (1989b) Regulation of Sertoli cell differentiated function: testicular transferrin and ABP expression. Endocrinology 124, 3015-3024. 
Speight, A., Clifford, J. \& Waites, G. (1984) Protein synthesis by cultured Sertoli cells isolated from prepubertal lamb testes. In Recent Progress in Cellular Endocrinology of the Testis (Coll. INSERM, vol. 123), pp. 199-204. Eds J. M. Saez, M. G. Forest, A. Dazord \& J. Bertrand. John Libbey, Paris.
Tananis Anthony, C. \& Skinner, M. (1989) Actions of extracellular matrix on Sertoli cell morphology and function. Biol. Reprod. 40, 691-702.

Received 11 December 1990 